\title{
ANALISIS PENGARUH KUALITAS LAYANAN TERHADAP KEPUASAN NASABAH MENGGUNAKAN ELECTRONIC BANKING
}

\author{
Ronny \\ ronny@perbanas.ac.id \\ Aniek Maschudah Ilfitriah \\ Mochamad Nurhadi \\ Universitas Hayam Wuruk Perbanas
}

\begin{abstract}
The purpose of this study is to analyze the effect of service quality dimensions on customer satisfaction in the use of e-banking which includes tangibles, reliability, responsibility, assurance, and empathy variables. E-banking products are limited to bank services with internet banking and mobile banking. Data was collected by distributing questionnaires to 132 respondents online to bank customers in Indonesia who have used internet banking or mobile banking. The data that has been collected is processed with the SPSS application and analyzed for validity, reliability, classical assumptions and hypothesis testing with multiple Linear Regression. The results showed that the Reliability variable and the Empathy variable had a significant effect on customer satisfaction, while the Responsiveness, Assurance, and Tangible variables had no significant effect on customer satisfaction using bank e-banking. The implication of this research is that banks need to improve reliability by maintaining the availability of internet banking and mobile banking applications so that they can be accessed by customers properly, and maintaining services that care about the problems and obstacles faced by customers in using e-banking.
\end{abstract}

Key words: service quality, electronic banking, customer satisfaction

\begin{abstract}
ABSTRAK
Tujuan dari penelitian ini adalah untuk menganalisis pengaruh dimensi kualitas layanan terhadap kepuasan nasabah dalam penggunaan e-banking yang meliputi variabel tangibles, reliability, responsibility, assurance, dan empathy. Produk e-banking dibatasi pada layanan bank dengan internet banking dan mobile banking. Data dikumpulkan dengan penyebaran kuesioner kepada 132 responden secara online kepada para nasabah bank di Indonesia yang pernah menggunakan internet banking atau mobile banking. Data yang telah dikumpulkan diolah dengan aplikasi SPSS dan dianalisis uji validitas, reliabilitas, asumsi klasik dan uji hipotesis dengan Regresi Linear berganda. Hasil penelitian menunjukkan bahwa variabel Reliability dan variabel Empathy berpengaruh signifikan terhadap Kepuasan nasabah, sedangkan variabel Responsiveness, Assurance, dan Tangibles berpengaruh tidak signifikan terhadap Kepuasan nasabah pengguna e-banking bank. Implikasi penelitian ini bagi pihak perbankan perlu meningkatkan keandalan dengan menjaga ketersediaan aplikasi internet banking dan mobile banking agar dapat diakses oleh nasabah dengan baik, dan menjaga layanan yang peduli atas masalah dan kendala yang dihadapi nasabah dalam menggunakan e-banking.
\end{abstract}

Kata kunci: kualitas layanan, electronic banking, kepuasan nasabah

\section{PENDAHULUAN}

Teknologi informasi merupakan sumber daya dalam industri perbankan yang amat kompetitif memberikan banyak manfaat diantaranya meningkatkan kinerja karyawan bank, biaya rendah, dan inovasi. Teknologi informasi digunakan juga untuk meningkat- kan layanan bank, sehingga nasabah memperoleh layanan yang cepat dan mudah. Teknologi informasi dalam layanan bank sering disebut electronic banking (disingkat $e$ banking), contoh e-banking antara lain internet banking, mobile banking. 
Beberapa manfaat layanan e-banking diantaranya transaksi dapat berlangsung 24 jam setiap hari, nasabah tidak harus datang ke kantor bank atau ke mesin ATM tetapi cukup melakukan transaksi dari mana saja dengan menggunakan perangkat elektronik yang terhubung internet, beragam layanan disediakan melalui fitur pada aplikasi bank seperti transfer uang, cek saldo, cek mutasi, beli pulsa, bayar listrik, dan fitur lainnya. Nasabah mudah dan cepat melaksanakan transaksi secara mobile. Bagi pihak perbankan menghadapi tantangan besar terhadap empat perkembangan yang terjadi di masyarakat, yakni pertama, tingginya kompetisi antar bank dalam layanannya; kedua, berkembangnya teknologi informasi dengan kecanggihan pada kecepatan dan keakuratan proses data sehingga menimbulkan daya tarik bagi penggunanya; ketiga, meningkatnya adopsi teknologi informasi khususnya penggunaan internet; keempat: beragam pemanfaatan internet diantaranya untuk perdagangan dilengkapi fasilitas pembayaran yang terkoneksi dengan e-banking. Keempat perkembangan tersebut merupakan faktor pendorong industri bank untuk menyelenggarakan layanan e-banking dengan optimal yang dapat memberikan kepuasan bagi nasabahnya.

Salah satu yang dapat menjadi ukuran penentu keberhasilan suatu layanan bank termasuk layanan e-banking yang diselenggarakan bank adalah mengukur kualitas layanan. Beberapa model kualitas layanan telah dikembangkan melalui penelitian dengan berbagai macam variabel, diantaranya: Fida et al. (2020) dan Khan et al. (2018) dengan variabel tangibles, reliability, responsebility, assurance, dan emphaty; Al-hawary dan Al-Smeran (2017) dengan variabel reliability, ease of use, efficiency, website design, privacy, responsiveness. Beberapa model kualitas layanan diteliti untuk beberapa kasus ebanking diantaranya: Khan et al. (2018), Gupta dan Bansal (2012), Al-hawary dan AlSmeran (2017), Nimako et al. (2013). Penelitian tersebut meneliti tentang pengaruh kualitas layanan terhadap kepuasan nasabah dengan maksud agar dapat mempertahankan retensi nasabah. Persaingan dalam industri perbankan menuntut bank perlu mengukur serta meningkatkan Laynan yang diberikan kepada nasabah. Perkembangan teknologi yang juga diikuti oleh kemungkinan terjadi kejahatan perbankan mendorong bank saat ini untuk meningkatkan kewaspadaan dengan mempersiapkan sistem transaksi bank yang lebih aman dan terpercaya. Ketidakpercayaan nasabah akibat ketidakpuasan terhadap layanan perbankan akan mudah bank itu ditinggalkan nasabahnya.

Tujuan dari penelitian ini adalah untuk menganalisis pengaruh dimensi kualitas layanan terhadap kepuasan nasabah dalam penggunaan e-banking bank di Indonesia.

\section{TINJAUAN TEORITIS \\ Grand Theory}

Menurut Kotler dan Keller (2016) semakin tinggi tingkat persaingan, akan menyebabkan pelanggan menghadapi lebih banyak alternatif pilihan produk, harga dan kualitas yang bervariasi, sehingga pelanggan akan selalu mencari nilai yang dianggap paling tinggi dari beberapa produk. Kualitas yang rendah akan menimbulkan ketidakpuasan. Oleh karena itu, penting untuk dapat dilakukan upaya perbaikan sistem kualitas layanan bagi keberlangsungan bisnis, dimana dengan adanya kualitas layanan yang baik nilai yang dihantarkan kepada pelanggan menjadi lebih positif, dan akan memberikan kepuasan kepada konsumen. Menurut Fida et al. (2020), kualitas layanan (Service Quality) memiliki lima dimensi yang mewakili kualitas layanan yang terdiri dari tangibles, empathy, reliability, responsiveness dan assurance. Tujuan dari penelitian ini ialah menguji dan menganalisis pengaruh service quality terhadap kepuasan pelanggan dan relevan pada industri perbankan di Indonesia khususnya layanan bank berbasis teknologi informasi yang sering dikenal dengan sebutan $e$-banking. 


\section{a. Reliability}

Menurut Fida et al. (2020) bahwa Reliability (keandalan) yaitu kemampuan untuk memberikan jasa yang dijanjikan dengan andal dan akurat. Dalam arti luas, keandalan dapat diartikan bahwa perusahaan memberikan janji-janjinya tentang penyediaan (produk atau jasa yang ditawarkan), penyelesaian masalah dan harga yang diberikan. Dalam penelitian Gupta dan Bansal (2012), Reliability adalah tanggungjawab bank untuk melakukan perbaikan jika terjadi kesalahan internet banking, dan ketersediaan website yang tidak berhenti saat nasabah memasukkan data transaksinya.

Menurut Al-Hawary dan Al-Smeran (2017), Reliability diukur berdasarkan kemampuan perusahaan untuk menyediakan situs web secara permanen dan benar; kemampuan perusahaan untuk menyampaikan kualitas informasi yang sesuai dengan kriteria ketepatan waktu, akurasi, pemahaman, relevansi; dan kemampuan perusahaan untuk memenuhi janji kepada pelanggan sehingga mencapai tingkat kepuasan yang tinggi.

Dari penelitian Gupta dan Bansal (2012), Fida et al. (2020), dan Al-Hawary dan AlSmeran (2017), konsep Reliability dalam ebanking dapat ditinjau dari aspek ketersediaan e-banking yang dapat diakses dengan daya tahan yang baik sebagaimana dijanjikan oleh bank. Dari perspektif pengguna (nasabah) ketersediaan dan keteraksesan $e$ banking bank ditinjau pula dari kemampuan aplikasi e-banking bank dapat diakses dari berbagai perangkat teknologi (gadget) yang digunakan oleh nasabah.

\section{b. Responsiveness}

Menurut Fida et al. (2020) bahwa Responsiveness (daya tanggap) yaitu kesadaran dan keinginan untuk membantu pelanggan dan memberikan jasa dengan cepat. Dimensi ini lebih pada menekankan perhatian dan ketepatan ketika berurusan dengan permintaan, pertanyaan dan keluhan pelanggan (nasabah).

Penelitian Gupta dan Bansal (2012), Responsiveness adalah mengukur respon bank ketika nasabah mengalami masalahmasalah dalam penggunaan internet banking, dan tersedianya jawaban atas pertanyaan atau masalah yang umum dihadapi nasabah dalam penggunaan internet banking. Dalam penelitian Al-Hawary dan Al-Smeran (2017), Responsiveness adalah daya tanggap secara umum sebagai kemampuan untuk memperbaiki produk atau memodifikasi layanan ketika terjadi masalah, karena konsumen tidak memiliki keahlian yang cukup untuk memproses dan memperbaiki, dan daya tanggap layanan elektronik yang dikenal sebagai respon cepat dan mendapatkan bantuan dalam kasus masalah atau pertanyaan.

Responsiveness dalam penelitian ini dimaknai sebagai kemampuan bank dalam menyelenggarakan e-banking memberikan tanggapan yang cepat dan mudah dan mampu melakukan proses transaksi yang tepat.

c. Tangibles

Menurut Fida et al. (2020) bahwa Tangibles yaitu berupa penampilan fasilitas fisik, peralatan, pegawai, dan material yang dipasang. Dimensi ini menggambarkan wujud secara fisik dan layanan yang akan diterima oleh konsumen. Oleh karena itu, penting bagi perusahaan untuk memberikan impresi yang positif terhadap kualitas layanan yang diberikan tetapi tidak menyebabkan harapan pelanggan yang terlalu tinggi. Hal ini meliputi lingkungan fisik seperti interior outlet, penampilan personil yang rapi dan menarik saat memberikan jasa.

Penelitian Ejigu (2016), Tangibles adalah penampilan fasilitas fisik, peralatan, personel dan bahan komunikasi. Ini berhubungan terhadap tampilan fisik e-banking. Lingkungan sekitar harus dijaga kebersihannya dengan cara bank menyediakan tempat sampah untuk sampah. Personil yang memberikan bimbingan kepada pelanggan juga harus terlihat rapi..

d. Assurance

Menurut Fida et al. (2020) bahwa Assurance yaitu pengetahuan, sopan santun, dan kemampuan karyawan untuk menimbulkan keyakinan dan kepercayaan. Dime- 
nsi ini mungkin akan sangat penting pada jasa layanan yang memerlukan tingkat kepercayaan cukup tinggi dimana pelanggan akan merasa aman dan terjamin.

Dalam penelitian Khan et al. (2018), Assurance menyinggung pembelajaran poekerja dan kerendahan hati dan kapasitas untuk menyampaikan kepercayaan dan kesungguhan.

Dalam penelitian Nimako et al. (2013), Assurance adalah jaminan layanan tentang keandalan dan kredibilitas transaksi, proteksi keamanan data transaksi, dan kepercayaan nasabah atas transaksi melalui internet banking.

Dalam penelitian ini, Assurance adalah penyelenggaraan e-banking yang aman, transaksi diproses dengan benar dan jaminan akan informasi yang berkualitas tersajikan dalam layanan e-banking.

e. Empathy

Menurut Tjoanoto (2013) Empathy yaitu kepedulian dan perhatian secara pribadi yang diberikan kepada pelanggan. Inti dari dimensi empati adalah menunjukkan kepada pelanggan melalui layanan yang diberikan bahwa pelanggan itu spesial, dan kebutuhan pelanggan dapat dipahami.

Dalam penelitian Ejigu (2016), Empathy adalah perhatian individual kepada pelanggan, bagaimana bank peduli pelanggan yang menggunakan e-banking. Ada kalanya $e$ banking benar-benar down dan nasabah dibiarkan terlantar dan hasil akhirnya adalah keluhan bahwa bank tidak peduli. Namun, ketika bank telah memilih untuk mimbuka pintu bagi pelanggan di luar jam kerja normal bank untuk memenuhi kebuntuhan pelanggan maka pelanggan merasakan emphaty bank.

Dalam penelitian ini, Empathy berkaitan dengan kebutuhan transaksi nasabah, edukasi, mengatasi kesulitan nasabah, dan komunikasi menjadi perhatian dan kepedulian pihak bank dalam layanan e-banking.

\section{Penelitian Terdahulu}

Lomendra et al. (2019) melakukan eksplorasi dampak Dimensi Kualitas Layanan pada Kepuasan Nasabah menggunakan SERVQUAL model, untuk menguji dampak reliability, responsiveness, assurance, empathy dan tangibles pada Kepuasan Nasabah di Bank Mauritius, dengan 200 nasabah bank yang dipilih secara acak. Hasil penelitian menunjukkan bahwa Reliability akurat dapat meningkatkan kualitas layanan di industri perbankan. Lima dimensi kualitas layanan yang diuji signifikansinya terhadap kepuasan nasabah di Bank menunjukkan variabel Reliability dan Empahty berpengaruh signifykan positif terhadap Kepuasan nasabah bank.

Penelitian Pakurar et al. (2019) mengasumsikan bank harus memenuhi kebutuhan nasabah merupakan cara bank agar dapat berkelanjutan. Penelitian dilakukan untuk menguji dimensi kualitas layanan, menggunakan SERVQUAL model, yang digunakan untuk mengukur kepuasan nasabah, meliputi dimensi tangibles, responsiveness, empthy, assurance, reliability, access, financial aspect, dan employee competences. Penelitian dilakukan pada nasabah bank di Jordania. Hasil penelitian menunjukkan bahwa assurance, reliability, access and employee competences merupakan faktor utama yang mempengaruhi kepuasan nasabah.

Penelitian yang juga menguji pengaruh variabel terhadap kepuasan nasabah diantaranya penelitian Al Dugaishem dan Khawaja (2017) menemukan hasil bahwa variabel reliability, efficiency, response dan empathy berpengaruh positif dan signifikan terhadap kepuasan nasabah.

Penelitian Firdous dan Faroqi (2017) pada 194 nasabah pengguna internet banking bank dimaksudkan untuk memahami dimensi yang berpengaruh terhadap kepuasan nasabah. Hasil penelitian dimensi kualitas layanan $e$-banking yang berpengaruh signifykan terhadap kepuasan nasabah adalah efficiency, system availability, fulfillment, privacy, contact, responsiveness dan contact individually.

Penelitian Vetriel et al. (2020) menguji dimensi kualitas layanan internet banking dan pengaruhnya pada kepuasan nasabah. Hasil 
penelitian pada 250 nasabah menunjukkan bahwa terdapat lima dimensi kualitas layanan internet banking bank yakni Responsiveness, Trust, Convenience, Efficiency dan Security.

Penelitian Nagar dan Ghai (2019), Perbankan elektronik merupakan saluran elektronik dengan seperangkat alat yang memungkinkan pelanggan perbankan untuk melakukan transaksi keuangan. Studi ini diperoleh kesimpulan bahwa keandalan adalah faktor yang paling krusial dan memiliki pengaruh signifikan pada pelanggan terhadap adopsi layanan e-banking.

Penelitian Mohalingam dan Janathanan (2018), hasil penelitian menunjukkan bahwa dampak e-banking memiliki efek positif pada nasabah Hatton National Bank PLC. Itu karena, semua variabel yaitu kenyamanan, keandalan, daya tanggap, keamanan dan biaya berkorelasi dengan hubungan positif yang kuat, dan tingkat signifikansi mereka di bawah 0,05 . Studi ini juga menunjukkan bahwa kenyamanan, keamanan dan biaya (biaya dan ongkos) adalah faktor utama yang berkontribusi untuk memuaskan nasabah e-banking di HNB PLC.

Penelitian Khan et al. (2018) untuk memahami hubungan antara kualitas Laynan dan kepuasan nasabah menggunakan mobile banking melalui model persamaan struktural di Bangladesh, kuesioner yang dibagikan kepada 240 responden, pemodelan PLS-SEM. Hasil penelitian menunjukkan bahwa ada pengaruh positif dan signifikan dari semua konstruk kualitas layanan yaitu, tangibility, reliability, responsiveness, assurance dan emphaty pada pelanggan.

Penelitian Yusuf dan Bala (2015) melakukan penelitian empiris tentang faktor-faktor yang mempengaruhi persepsi kepuasan nasabah perbankan elektronik dan hubungan antara faktor-faktor itu terhadap kepuasan nasabah. Studi ini membantu industri bank dalam meningkatkan tingkat kepuasan nasabah mereka dan meningkatkan ikatan antara bank dan nasabahnya. Hasil penelitian menunjukkan bahwa availability, convenience, efficiency, fulfillment, privacy dan reliability berimplikasi mempengaruhi persepsi kepuasan pelanggan tentang electronic banking.

\section{Kepuasan Pelanggan}

Menurut Uwalaka dan Eze (2020), kepuasan pelanggan mengacu pada utilitas yang dirasakan oleh pelanggan terhadap produk atau layanan yang ditawarkan bank. Secara singkat, kepuasan pelanggan biasa didefinisikan sebagai evaluasi setelah pelanggan menggunakan suatu produk serta apakah dapat memenuhi harapan dari pelanggan. Ketika kenyataan sama atau lebih tinggi dari harapan, maka pelanggan merasa puas, dan pelanggan yang merasa puas akan setia terhadap suatu produk, melakukan promosi dari mulut ke mulut (Word of Mouth), akan mempertimbangkan membeli ulang produk dimana dia merasa puas (Kotler dan Keller, 2016). Berdasarkan dari pernyataan Kotler dan Keller (2016), maka dapat disimpulkan bahwa kepuasan pelanggan menjadi faktor yang sangat penting bagi perusahaan agar dapat tetap bertahan bahkan untuk bertumbuh. Dalam penelitian ini, kepuasan nasabah dipandang sebagai kondisi yang dirasakan nasabah atas pengalamannya menggunakan e-banking, puas yang diwujudkan dalam keinginan untuk terus menggunakan layanan $e$-banking bank.

\section{Hubungan Antar Variabel Penelitian}

Keterkaitan antar variabel bebas dengan variabel terikat yang menjadi variabel dalam penelitian ini akan dijelaskan sebagai berikut:

\section{Pengaruh Variabel Reliability terhadap} Variabel Kepuasan nasabah e-banking

Hubungan antara variabel Reliability (keandalan) terhadap variabel Kepuasan berdasarkan penelitian Lomendra et al (2019), Pakurar et al. (2019), Al Dugaishem dan Khawaja (2017), Khan et al. (2018), Yusuf dan Bala (2015) adalah menghasilkan sebuah hubungan yang positif signifikan. Artinya semakin tinggi tingkat keandalan produk suatu bank yang dirasakan nasabah maka 
semakin tinggi tingkat kepuasan yang dirasakan oleh nasabah. Begitu juga dengan nasabah sebagai pengguna e-banking jika dapat merasakan ketersediaan akses $e$ banking, dan mampu mengakses e-banking bank dari berbagai perangkat teknologi yang digunakan nasabah akan menciptakan kepuasan nasabah dalam melakukan transaksi perbankan dengan $e$-banking.

$\mathrm{H}_{1}$ : Dimensi variabel Kualitas Layanan yaitu Reliability berpengaruh signifikan positif terhadap kepuasan nasabah $e$-banking.

\section{Pengaruh Variabel Responsiveness terhadap Variabel Kepuasan nasabah e- banking}

Berdasarkan hasil penelitian Al Dugaishem dan Khawaja (2017), Khan et al. (2018), pengaruh variabel Responsiveness dalam hal ini kesadaran dan keinginan untuk membantu nasabah dan memberikan jasa dengan cepat terhadap kepuasan nasabah adalah positif signifikan. Artinya jika tingkat kesadaran bank untuk membantu dan melayani nasabah dengan cepat dapat dirasakan oleh nasabah maka tingkat kepuasan nasabah akan meningkat.

$\mathrm{H}_{2}$ : Dimensi variabel Kualitas Layanan yaitu Responsiveness berpengauh signifikan positif terhadap kepuasan nasabah e-banking.

\section{Pengaruh Variabel Assurance terhadap} Variabel Kepuasan nasabah $e$-banking

Tingkat pengetahuan, sopan santun dan kemampuan karyawan pada saat melayani nasabah akan menimbulkan keyakinan dan kepercayaan nasabah kepada bank khususnya kepada produk yang dipakai oleh nasabah yaitu layanan e-banking dan mendorong pada kepuasan nasabah. Dimensi ini sangat penting pada jasa layanan perbankan karena akan mendorong tingkat kepercayaan cukup tinggi dimana nasabah akan merasa aman dan terjamin. Hal ini berarti semakin tinggi tingkat pengetahuan, sopan santun, kemampuan karyawan dalam melayani nasabah e-banking maka akan semakin puas nasabah tersebut. Penelitian Pakurar et al. (2019), Khan et al. (2018) menunjukkan variabel Assurance berpengauh signifikan positif terhadap kepuasan nasabah e-banking.

$\mathrm{H}_{3}$ : Dimensi variabel Kualitas Layanan yaitu Assurance berpengaruh signifikan positif terhadap kepuasan nasabah e-banking.

\section{Pengaruh Variabel Tangibles terhadap Variabel Kepuasan nasabah e-banking}

Berdasarkan hasil penelitian Khan et al. (2018), hubungan variabel Tangibles terhadap kepuasan berhubungan positif signifikan. Hal ini berarti jika bank mampu menyediakan secara fisik kebutuhan transaksi $e$ banking akan meningkatkan kepuasan nasabah bank dalam bertransaksi e-banking. Kemampuan bank dalam menyiapkan lingkungan fisik seperti interior outlet, penampilan personil yang rapi dan menarik saat memberikan jasa pelayanan khususnya e-banking akan meningkatkan kepuasan nasabah e-banking.

$\mathrm{H}_{4}$ : Dimensi variabel Kualitas Layanan yaitu Tangibles berpengauh signifikan positif terhadap kepuasan nasabah e-banking.

\section{Pengaruh Variabel Empathy terhadap Variabel Kepuasan nasabah $e$-banking}

Sama dengan dismensi variabel kualitas layanan yang lain maka dimensi variabel Empathy juga memiliki hubungan positif signifikan dengan kepuasan. Hal ini dapat dijelaskan bahwa kepedulian dan perhatian secara pribadi dari karyawan bank diberikan kepada nasabah adalah salah satu bentuk Empathy. Inti dari dimensi Empathy adalah menunjukkan kepada nasabah melalui layanan yang diberikan bahwa nasabah itu spesial (utama) dan kebutuhan nasabah dapat dipenuhi dan harus dipahami. Penelitian Lomendra et al (2019), Al Dugaishem dan Khawaja (2017), Khan et al. (2018) berpengaruh signifikan terhadap variabel Kepuasan Nasabah.

$\mathrm{H}_{5}$ : Dimensi variabel Kualitas Layanan yaitu Empathy berpengaruh signifikan positif terhadap kepuasan nasabah e-banking. 


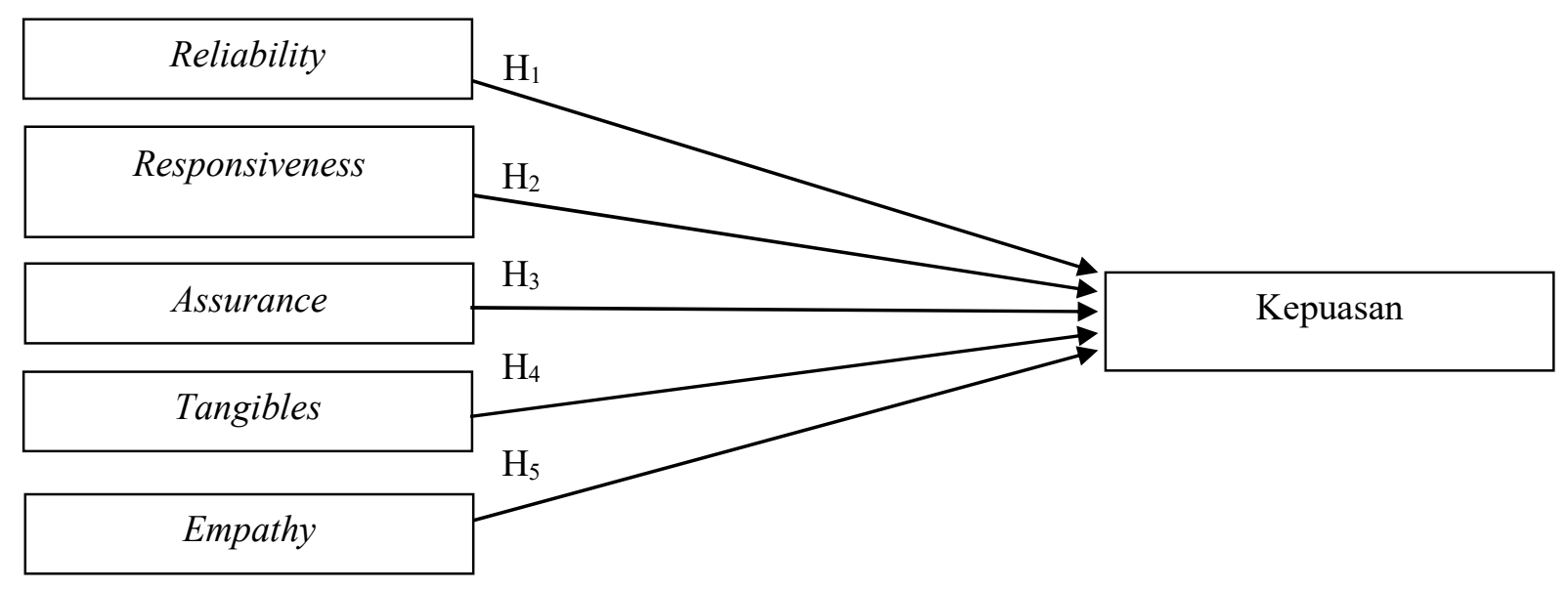

Gambar 1

Model Penelitian

\section{Model Penelitian}

Model penelitian yang dikembangkan dalam penelitian ini adalah sebagaimana pada Gambar 1.

\section{METODE PENELITIAN}

Jenis Penelitian dan Gambaran dari Populasi (Objek) Penelitian

Jenis Penelitian dan Gambaran dari Populasi (Objek) Penelitian ini menggunakan data primer, yaitu data yang diperoleh dari kegiatan penelitian lapangan dengan melakukan penyebaran kuesioner, jenis data yang digunakan adalah data kuantitatif. Populasi (subyek) dalam penelitian ini adalah nasabah yang menjadi pengguna $e$ banking di Indonesia yang dibatasi pada mobile banking dan internet banking, Responden dibatasi pula pada usia di atas 19 tahun.

\section{Teknik Pengambilan Sampel}

Hair et al. (2018) menyarankan bahwa banyak sampel penelitian dimana populasinya tidak diketahui jumlahnya, minimal lima kali variabel yang dianalisa atau indikator pernyataan. Jumlah indikator pernyataan dari kuesioner penelitian ini berjumlah 24, maka diperoleh hasil perhitungan sampel sebagai berikut: Jumlah sampel $=5 \mathrm{x}$ indikator variabel $=5 \times 24$ indikator variabel $=120$ sampel. Penelitian ini menggunakan
132 sampel berarti memenuhi persyaratan minimum 120 sampel.

\section{Teknik Pengumpulan Data}

Dalam penelitian ini digunakan teknik pengumpulan data survei dengan membagikan kuisioner kepada nasabah bank yang memenuhi kriteria responden, yakni pengguna e-banking telah berusia di atas 19 tahun. Kuisioner disusun dengan melibatkan sejumlah pernyataan yang perlu dijawab dalam bentuk pilihan jawaban, dengan bahasa yang mudah dimengerti dan tidak menimbulkan interpretasi ganda atau multitafsir.

\section{Definisi Operasional}

Setiap variabel dijelaskan sebagai berikut:

Reliability adalah pendapat responden pengguna $e$-banking dapat ditinjau dari aspek ketersediaan e-banking yang dapat diakses setiap kali dibutuhkan, jarang mengalami kegagalan, tidak sering logout saat adigunakan, dapat digunakan diberbagai perangkat teknologi.

Indikator variabel reliability meliputi ketersediaan $e$-banking yakni $e$-banking dapat diakses dan digunakan oleh nasabah; kegagalan akses yakni akses e-banking oleh nasabah tidak menimbulkan kekecewaan bagi nasabah; daya tahan e-banking adalah aplikasi $e$-banking dapat bertahan lama digunakan 
oleh nasabah; kompatibilitas perangkat adalah fleksibilitas e-banking dapat digunakan di berbagai perangkat teknologi informasi.

Responsiveness adalah pendapat responden terhadap kemampuan bank dalam menyelenggarakan e-banking memberikan tanggapan yang cepat, aplikasi mudah dipahami dan dioperasikan serta mampu melakukan proses transaksi yang tepat.

Indikator variabel ini meliputi kecepatan yakni proses transaksi dan penggunaan e-banking dengan waktu yang singkat; kemudahan yakni kemudahan dipelajari dan kemudahan digunakan aplikasi e-banking; ketepatan waktu adalah proses yang tepat berjalan sebagaimana mestinya atau sebagaimana yang dijanjikan.

Assurance adalah pendapat responden tentang kepercayaan nasabah akan Kamanan data, keamanan dalam bertransaksi menggunakan e-banking, transaksi diproses dengan benar dan jaminan akan informasi yang berkualitas tersajikan dalam layanan $e$ banking.

Indikator variabel ini meliputi keamanan yakni rasa aman yang dialami nasabah pada perlindungan data pribadi; jaminan edukasi yakni bank menjamin terjadinya edukasi terutama saat nasabah menghadapi kendala atau hambatan dalam menggunakan e-banking; pemrosesan transaksi dengan benar adalah transaksi e-banking memproses transaksi nasabah dengan akurat; kualitas informasi adalah keakuratan dan relevansi informasi yang tersedia.

Tangibles adalah pendapat responden tentang bukti fisik termasuk fasilitas dalam aplikasi/website bank berupa ketersediaan fitur, tampilan aplikasi, dan kemampuan personil.

Indikator variabel ini meliputi tampilan aplikasi $e$-banking yakni daya tarik tampilan aplikasi e-banking yang menarik; fitur yang lengkap adalah tersedianya berbagai fitur dalam aplikasi e-banking yang dibutuhkan oleh nasabah; kinerja personil adalah kemampuan sumber daya manusia bank yang dapat melayani dengan professional dan ramah.
Empathy adalah pendapat responden mengenai bagaimana bank mampu memenuhi kebutuhan transaksi nasabah, melakukan edukasi pada nasabah, mengatasi kesulitan nasabah, dan komunikasi yang baik dengan nasabah menjadi perhatian dan kepedulian pihak bank dalam layanan $e$ banking.

Indikator variabel ini meliputi kebutuhan transaksi nasabah yakni pemenuhan kebutuhan transaksi yang dibutuhkan nasabah melalui aplikasi e-banking; kebutuhan edukasi yakni nasabah memperoleh edukasi dari personil bank; penanganan complain yakni nasabah dilayani dengan baik saat menghadapi masalah; komunikasi yang baik yakni bank dan nasabah menjalin komunikasi yang baik.

Kepuasan Nasabah adalah pendapat responden tentang kepuasan dalam meonggunakan e-banking, transaksi $e$-banking, kualitas layanan tidak mengecewakan dan akan menggunakan terus layanan e-banking.

Indikator variabel ini meliputi kepuasan menggunakan e-banking bahwa nasabah merasakan kepuasan atas penggunaan $e$ banking; keinginan terus menggunakan $e$ banking bahwa karena merasa puas maka nasabah ingin terus menggunakan e-banking; kekecewaan yang tidak ada bahwa nasabah tidak merasakan kekecewaan yang berarti dalam menggunakan $e$-banking bank.

\section{Pengukuran Variabel}

Pengukuran variabel yang digunakan dalam penelitian ini adalah skala likert. Skala likert adalah skala yang dirancang untuk memeriksa seberapa kuat pernyataan responden setuju atau tidak setuju Skor 5 untuk "Sangat Setuju", Skor 4 untuk "Setuju", Skor 3 untuk "Ragu-ragu", Skor 2 untuk "Tidak Setuju", Skor 1 untuk "Sangat Tidak Setuju".

\section{Model Analisis}

Analisis yang digunakan dalam penelitian ini adalah regresi linier berganda dengan model regresi sebagai berikut:

$\mathrm{Y}=\alpha+\beta_{1} \mathrm{REL}+\beta_{2} \mathrm{RES}+\beta_{3} \mathrm{ASS}_{+} \beta_{4} \mathrm{TAN}+\beta_{5} \mathrm{EMP}+\mathrm{e}$ 
Keterangan:

$$
\begin{array}{ll}
\mathrm{Y} & =\text { Kepuasan Nasabah } \\
\mathrm{a} & =\text { Konstanta } \\
\mathrm{REL} & =\text { Reliability } \\
\mathrm{RES} & =\text { Responsiveness } \\
\mathrm{ASS} & =\text { Assurance } \\
\mathrm{TAN} & =\text { Tangible } \\
\mathrm{EMP} & =\text { Empathy } \\
\beta_{1-5} & =\text { Estimasi koefisien regresi } \\
\mathrm{e} & =\text { Standart error }
\end{array}
$$

\section{ANALISIS DAN PEMBAHASAN}

Berdasarkan hasil survey terhadap 132 responden dapat diperoleh gambaran umum responden yang telah berkontribusi seperti pada Tabel 1 yang dapat memberikan gambaran tentang usia, pendidikan terakhir, pekerjaan dan jenis kelamin. Berdasarkan usia responden berumur $26 \mathrm{~s} / \mathrm{d} 35$ tahun adalah usia terbanyak yang mengisi kuesioner yaitu sebanyak 47 orang atau
$35,61 \%$ dari total responden. Sedangkan kategori usia terbanyak kedua adalah pada usia diatas 45 tahun yaitu sebanyak 38 orang atau sekitar $28,79 \%$ dari total responden. Jika dilihat dari pendidikan terakhir responden rata-rata sudah berpendidikan S1 dan S2 yaitu mencapai $88,63 \%$ ini artinya bahwa pendapat responden dapat dipertanggung jawabkan sesuai dengan strata/ jenjang pendidikannya. Sebagian besar responden bekerja pada instansi swasta yaitu sebanyak 82 orang atau sekitar $62,12 \%$ dari total responden, sedangkan yang bekerja sebagai PNS sebanyak 23 orang atau 17,42\% dari total responden. Sisanya bekerja sebagai

\begin{tabular}{|c|c|c|c|}
\hline \multicolumn{4}{|c|}{ Responden Berdasarkan Usia } \\
\hline Item & Skala & Jumlah Responden & Prosentase (\%) \\
\hline \multirow[t]{4}{*}{ Usia } & $19 \mathrm{~s} / \mathrm{d} 25$ tahun & 22 & 16,67 \\
\hline & $26 \mathrm{~s} / \mathrm{d} 35$ tahun & 47 & 35,61 \\
\hline & $36 \mathrm{~s} / \mathrm{d} 45$ tahun & 25 & 18,94 \\
\hline & $>45$ tahun & 38 & 28,79 \\
\hline \multicolumn{4}{|c|}{ Responden Berdasarkan Pendidikan Terakhir } \\
\hline Item & Skala & Jumlah Responden & Prosentase $(\%)$ \\
\hline \multirow[t]{4}{*}{ Pendidikan Terakhir } & SD/SMP/SMA & 10 & 7,58 \\
\hline & S1 & 60 & 45,45 \\
\hline & S2 & 57 & 43,18 \\
\hline & S3 & 5 & 3,79 \\
\hline \multicolumn{4}{|c|}{ Responden Berdasarkan Pekerjaan } \\
\hline Item & Skala & Jumlah Responden & Prosentase (\%) \\
\hline \multirow[t]{4}{*}{ Pekerjaan } & PNS & 23 & 17,42 \\
\hline & Karyawan Swasta & 82 & 62,12 \\
\hline & Wiraswasta & 15 & 11,36 \\
\hline & Belum bekerja & 12 & 9,09 \\
\hline \multicolumn{4}{|c|}{ Responden berdasarkan Jenis Kelamin } \\
\hline Item & Skala & Jumlah Responden & Prosentase (\%) \\
\hline \multirow[t]{2}{*}{ Jenis Kelamin } & Laki-Laki & 61 & 46,21 \\
\hline & Perempuan & 71 & 53,79 \\
\hline
\end{tabular}
wiraswasta $11,36 \%$ dan 12 orang lainnya menyatakan belum bekerja. Responden yang bersedia mengisi kuesioner dalam penelitian ini sebanyak 71 orang wanita atau 53,79\%, sedangkan sisanya $46,21 \%$ berjenis kelamin laki-laki.

Tabel 1

Gambaran Umum Responden Penelitian 


\section{Analisis Statistik Deskriptif}

Tabel 2 menunjukkan hasil olah data statistik deskriptif jawaban responden berdasarkan skor terendah, tertinggi dan rata-rata dari seluruh dimensi variabel kualitas layanan yang diteliti. Dimensi variabel Reliability, rata-rata responden menyatakan "Setuju" bahwa Reliability atau Keandalan layanan e-banking bank di Indonesia dengan rata-rata skor 3,96. Untuk skor maksimum 4,28 pada pernyataan " $E$ banking bank di Indonesia relative tersedia (berhasil diakses) setiap saat dibutuhkan", untuk skor minimum sebesar 3,77 pada pernyataan "E-banking bank di Indonesia jarang mengalami kegagalan akses". Pada dimensi variabel Responsiveness, rata-rata responden menyatakan "Setuju" bahwa Responsiveness dalam layanan e-banking bank di Indonesia dengan rata-rata skor 4,07. Untuk skor maksimum 4,14 pada pernyataan "Aplikasi e-banking bank di Indonesia mudah dioperasikan", untuk skor minimum sebesar 3,95 pada pernyataan "Informasi dalam aplikasi e-banking bank di Indonesia mudah dipahami".

Tabel 2

Analisis Statistik Deskriptif Variabel

\begin{tabular}{lcccc}
\hline \multicolumn{1}{c}{ Variabel } & N & Max & Min & $\begin{array}{c}\text { Rata- } \\
\text { Rata }\end{array}$ \\
\hline \hline Reliability & 132 & 4,28 & 3,77 & 3,96 \\
Responsiveness & 132 & 4,14 & 3,95 & 4,07 \\
Assurance & 132 & 4,13 & 3,56 & 3,81 \\
Tangibles & 132 & 3,97 & 3,72 & 3,86 \\
Empathy & 132 & 4,12 & 3,68 & 3,91 \\
Kepuasan & 132 & 4,11 & 4,02 & 4,07 \\
\hline
\end{tabular}

Sumber : data kuesioner, diolah

Dimensi variabel Assurance, rata-rata responden menyatakan "Setuju" bahwa Assurance dalam layanan e-banking bank di Indonesia dengan rata-rata skor 3,81. Untuk skor maksimum 4,13 pada pernyataan " $E$ banking bank di Indonesia memproses transaksi dengan benar", untuk skor minimum sebesar 3,56 pada pernyataan "Bank di Indonesia memberi edukasi yang memadai kepada nasabah tentang keamanan menggunakan e-banking". Variabel Tangible, rata-rata responden menyatakan "Setuju" bahwa Tangible dalam layanan e-banking bank di Indonesia dengan rata-rata skor 3,86 . Untuk skor maksimum 3,97 pada pernyataan "Personil bank melayani nasabah dengan ramah dalam layanan e-banking bank di Indonesia", untuk skor minimum sebesar 3,72 pada pernyataan "Aplikasi Ebanking Bank di Indonesia tampilannya menarik". Dimensi variabel Empathy, ratarata responden menyatakan "Setuju" bahwa Empathy dalam layanan e-banking bank di Indonesia dengan rata-rata skor 3,91. Untuk skor maksimum 4,12 pada pernyataan " $E$ banking bank di Indonesia mampu melayani kebutuhan transaksi nasabah", untuk skor minimum sebesar 3,68 pada pernyataan "Edukasi nasabah dijalankan dengan baik oleh bank di Indonesia tentang penggunaan ebanking".

Variabel Kepuasan, rata-rata responden menyatakan "Setuju" bahwa Kepuasan dalam layanan e-banking bank di Indonesia dengan rata-rata skor 4,07. Untuk skor maksimum 4,11 pada pernyataan "Saya akan terus menggunakan e-banking bank di Indonesia", untuk skor minimum sebesar 4,02 pada pernyataan "Saya puas dengan transaksi e-banking bank di Indonesia".

\section{Uji Validitas dan Reliabilitas}

Pengujian validitas dan reliabilitas dilakukan sebelum menguji hipotesis suatu penelitian. Pengujian validitas dan reliabilitas ini dilakukan dua macam, yakni sampel kecil sebanyak 30 kuesioner, dan sampel besar sebanyak 132 kuesioner dan dilakukan dengan menggunakan SPSS 16.0 for windows.

Hasil menunjukkan bahwa semua indikator dari variabel memiliki nilai signifikansi $0,00<0,05$ menunjukan Valid baik pada sampel kecil maupun sampel besar. Demikian pula, semua variabel menunjukkan nilai Cronbach's Alpha > 0,6 berarti Reliable, yakni untuk sampel kecil pada variabel Reliability nilai Cronbach's Alpha $=0,802$, variabel Responsiveness nilai 
Cronbach's Alpha = 0,804, variabel Assurance nilai Cronbach's Alpha $=0,832$, variabel Tangibles nilai Cronbach's Alpha $=0,623$, variabel Empathy nilai Cronbach's Alpha = 0,713, dan variabel Kepuasan nilai Cronbach's Alpha $=0,839$. Untuk sampel besar, pada variabel Reliability nilai Cronbach's Alpha $=0,739$, variabel Responsiveness nilai Cronbach's Alpha = 0,797, variabel Assurance nilai Cronbach's Alpha $=0,814$, variabel Tangibles nilai Cronbach's Alpha $=0,743$, variabel Empathy nilai Cronbach's Alpha $=0,768$, dan variabel Kepuasan nilai Cronbach's Alpha $=0,864$.

\section{Uji Asumsi Klasik}

Sebelum dilakukan uji statistik hipotesis penelitian maka terlebih dahulu dilakukan uji asumsi klasik. Pada uji asumsi klasik, uji Normalitas diperoleh hasil memenuhi asumsi normalitas karena nilai Sig. dari residual sebesar 0,391 >0,05. Untuk uji Multikolinieritas diperoleh hasil semua variabel tidak terjadi multikolinieritas karena nilai Tolerance untuk semua variabel $>0,1$ dan nilai VIF untuk semua variabel < 10, yakni nilai Tolerance untuk variabel Reliability sebesar 0,528, variabel Responsiveness sebesar 0,442, variabel Assurance sebesar 0,384, variabel Tangibles sebesar 0,427, variabel Empathy sebesar 0.395. Sedangkan VIF, untuk variabel Reliability sebesar 1,894, variabel Responsiveness sebesar 2,264, variabel Assurance sebesar 2,604, variabel Tangibles sebesar 2,344, variabel Empathy sebesar 2,533.

\section{Analisis Regresi Linear Berganda}

Setelah dilakukan uji asumsi klasik sebagai tahapan awal penelitian sebelum melakukan kajian multi regresi yang digunakan untuk uji hipotesis.

\section{Koefisien determinasi}

Koefisien determinasi dalam penelitian ini dilakukan untuk mengukur kekuatan hubungan dalam model penelitian antara variabel bebas dan terikat. Nilai dari koefisien determinasi berkisar antara nol sampai dengan satu, semakin mendekati angka satu dengan nilai $\mathrm{R}^{2}$ yang berarti kemampuan dari variabel independen dalam menerangkan variabel dependen memberikan informasi lengkap yang di butuhkan untuk dapat mengidentifikasi variasi dari variabel dependen.

Kerangka model pemikiran yang dibuat dalam penelitian berdasarkan uji $\mathrm{F}$ tes yaitu untuk mengukur tingkat signifikansi pengaruh variabel bebas yaitu Reliability, Responsiveness, Assurance, Tangibles, Empathy terhadap variabel terikatnya Kepuasan Nasabah secara bersama-sama menunjukkan pengaruh yang kuat dilihat dari hasil koefisien determinasi simultan Adjusted $\mathrm{R}$ Square sebesar 0,522 atau sebesar 52,2\% variabel bebas mendukung variabel terikatnya dimana semakin mendekati angka satu maka hubungan variabel bebas terhadap variabel terikatnya semakin kuat atau dalam hal ini sudah diatas $50 \%$.

Persamaan Regresi Linier Berganda adalah persamaan yang digunakan untuk melihat bentuk pengaruh dari masingmasing variabel bebas Reliability, Responsiveness, Assurance, Tangibles, Empathy terhadap variabel terikatnya Kepuasan Nasabah. Berikut ini akan disajikan hasil dari pengolahan data dengan menggunakan program SPSS versi 16 for windows yang ditunjukkan oleh Tabel 4 dan Tabel 5.

Tabel 3

Koefisien Determinasi Simultan

\begin{tabular}{lllll}
\hline Model & R & R Square & Adjusted R Square & Std. Error of the Estimate \\
\hline \hline 1 & .735 & .540 & .522 & 1.36639 \\
\hline \multicolumn{4}{l}{ Sumber: data kuesioner, diolah }
\end{tabular}

Sumber: data kuesioner, diolah 
Tabel 4 Hasil Koefisien Regresi

\begin{tabular}{lll}
\hline No & \multicolumn{1}{c}{ Variabel } & Koefisien Regresi \\
\hline \hline 1 & Contant & 3,147 \\
2 & Reliability & $0,238\left(\beta_{1}\right)$ \\
3 & Responsiveness & $0,111\left(\beta_{2}\right)$ \\
4 & Assurance & $0,122\left(\beta_{3}\right)$ \\
5 & Tangibles & $0,092\left(\beta_{4}\right)$ \\
$\mathbf{6}$ & Empathy & $0,273\left(\beta_{5}\right)$ \\
7 & Standar Error & 1,140 \\
\hline
\end{tabular}

Sumber: data kuesioner, diolah

Berdasarkan koefisien regresi pada Tabel 4 dapat dinyatakan persamaan regeresinya sebagai berikut:

$\mathrm{Y}=3,147+0,238 \mathrm{REL}+0,111 \mathrm{RES}+0,122 \mathrm{ASS}$ $+0,092 \mathrm{TAN}+0,273 \mathrm{EMP}+1,140$

Koefisien regresi $\beta_{1}=0,238$ menunjukkan bahwa variable Reliability memiliki hubungan positif dengan Kepuasan Nasabah, jika nilai Reliability naik satu satuan maka Kepuasan Nasabah akan naik 0,238. jika nilai Reliability turun satu satuan maka Kepuasan Nasabah akan turun sebesar 0,238.

Koefisien regresi $\beta_{2}=0,111$ menunjukkan bahwa variable Responsiveness memiliki hubungan positif dengan Kepuasan Nasabah, jika nilai Responsiveness naik satu satuan maka Kepuasan Nasabah akan naik 0,111. jika nilai Responsiveness turun satu satuan maka Kepuasan Nasabah akan turun sebesar 0,111 .

Koefisien regresi $\beta_{3}=0,122$ menunjukkan bahwa variable Assurance memiliki hubungan positif dengan Kepuasan Nasabah, jika nilai Assurance naik satu satuan maka Kepuasan Nasabah akan naik 0,122. jika nilai Assurance turun satu satuan maka Kepuasan Nasabah akan turun sebesar 0,122.

Koefisien regresi $\beta_{4}=0,092$ menunjukkan bahwa variable Tangibles memiliki hubungan positif dengan Kepuasan Nasabah, jika nilai Tangibles naik satu satuan maka Kepuasan Nasabah akan naik 0,092. jika nilai Tangibles turun satu satuan maka Kepuasan Nasabah akan turun sebesar 0,092.
Koefisien regresi $\beta_{5}=0,273$ menunjukkan bahwa variable Emphaty memiliki hubungan positif dengan Kepuasan Nasabah, jika nilai Emphaty naik satu satuan maka Kepuasan Nasabah akan naik 0,273. jika nilai Emphaty turun satu satuan maka Kepuasan Nasabah akan turun sebesar 0,273.

\section{Uji Hipotesis}

Analisis pengaruh antar variabel seperti disampaikan pada hipotesis 1 sampai dengan hipotesis 5 dapat disimpulkan bedasarkan Tabel 5 dan diuraikan sebagai berikut: $\mathrm{H}_{1}$ : Reliability berpengaruh positif signifikan terhadap kepuasan nasabah e-banking di Indonesia dengan nilai Sig. 0,004 $<0,05$ dengan $\mathrm{t}$ statistic 2,968 $>\mathrm{t}$ tabel 1,96.

$\mathrm{H}_{2}$ : Responsiveness berpengauh positif tidak signifikan terhadap kepuasan nasabah $e$ banking di Indonesia dengan nilai Sig. 0,225 > 0,05 dengan $\mathrm{t}$ statistic $1,219<\mathrm{t}$ tabel 1,96 .

$\mathrm{H}_{3}$ : Assurance berpengaruh positif tidak signifikan terhadap kepuasan nasabah $e$ banking di Indonesia dengan nilai Sig. 0,147 > 0,05 dengan $\mathrm{t}$ statistic $1,459<\mathrm{t}$ tabel 1,96 .

$\mathrm{H}_{4}$ : TangibleS berpengaruh positif tidak signifikan terhadap kepuasan nasabah $e$ banking di Indonesia dengan nilai Sig. 0,332> 0,05 dengan $t$ statistic $0,973<\mathrm{t}$ tabel 1,96.

$\mathrm{H}_{5}$ : Empathy berpengauh positif signifikan terhadap kepuasan nasabah e-banking di Indonesia dengan nilai Sig. 0,004 $<0,05$ dengan $\mathrm{t}$ statistic 2,975 $>\mathrm{t}$ tabel 1,96 .

\section{Tabel 5}

Hasil Uji t

\begin{tabular}{llccc}
\hline No & Variabel & Sig & $\begin{array}{c}\text { Batas } \\
\text { Sig }\end{array}$ & t \\
\hline \hline 1 & Reliability & 0,004 & $<0,05$ & 2.968 \\
2 & Responsiveness & 0,225 & $<0,05$ & 1.219 \\
3 & Assurance & 0,147 & $<0,05$ & 1.459 \\
4 & Tangible & 0,332 & $<0,05$ & 0.973 \\
5 & Empathy & 0,004 & $<0,05$ & 2.975
\end{tabular}

Sumber: data kuesioner, diolah

\section{Pembahasan}

Berdasarkan tujuan penelitian dan hasil uji statistik terhadap 132 responden nasabah 
bank untuk menguji kepuasan nasabah pengguna e-banking berdasarkan dimensi variabel Reliability, Empathy, Responsiveness, Assurane, Tangibles maka dapat diuraikan pembahasan sebagai berikut:

\section{Hasil Uji Regresi}

Berdasarkan hasil Uji T-test dan model persamaan regresi bahwa nilai konstanta sebesar 3,147 menunjukkan bahwa seorang nasabah jika tidak didukung oleh variabel bebas Reliability, Responsiveness, Assurance, Tangibles, Empathy maka tingkat kepuasan yang dirasakan oleh nasabah e-banking adalah sebesar 3,147. Dengan besaran Kofisien determinasi $52,2 \%$ yang menunjukkan besarnya pengaruh Reliability, Responsiveness, Assurance, Tangibles, Empathy pada variabel Kepuasan, dan masih ada faktorfaktor lain diluar variabel tersebut, yaitu sebesar $47,8 \%$ yang mendukung kepuasan nasabah pengguna $e$-banking diluar variabel yang diukur dalam penelitian ini.

\section{Pengaruh variabel Reliability terhadap variabel Kepuasan}

Tingkat Reliability nasabah e-banking di Indonesia berpengaruh signifikan positif terhadap kepuasan nasabah. Hal ini berarti semakin tinggi tingkat Reliabiality dirasakan nasabah e-banking maka semakin tinggi tingkat kepuasan nasabah. Faktor pendorong tingkat Reliability nasabah tertinggi adalah terletak pada item e-banking di Indonesia relative tersedia (berhasil diakses) setiap saat dibutuhkan, yang mana sebagian besar responden menyatakan sangat setuju dengan skor skala Likert mencapai 4,28 dari total skor 5 . Item pernyataan tertinggi kedua adalah e-banking bank di Indonesia relative dapat diakses di berbagai perangkat teknologi memiliki skor sebesar 3,95 dari total skor 5. Item pernyataan e-banking bank di Indonesia jarang mengalami kegagalan akses memiliki skor 3,77 atau masuk dalam kategori setuju sedangkan item pernyataan bahwa aplikasi e-banking bank di Indonesia setiap kali digunakan bisa aktif (tidak logout) dalam beberapa waktu lamanya memiliki skor 3,86 juga masuk dalam kategori setuju.

Dengan demikian secara keseluruhan rata-rata responden yang menyatakan setuju dengan skor sebesar 3,96 bahwa tingkat Reliability yang dirasakan nasabah e-banking mendukung tingkat kepuasan nasabah. Hasil penelitian ini sejalan dengan penelitian Lomendra et al (2019), Pakurar et al. (2019), Al Dugaishem dan Khawaja (2017), Khan et al. (2018), Yusuf dan Bala (2015) dan sesuai dengan pengembangan teori kualitas layanan khususnya dibidang perbankan bahwa semakin tinggi pihak bank mampu memberikan hal-hal yang positif sesuai keinginan nasabah maka akan meningkatkan kepuasan nasabah khususnya dalam Onggunaan teknologi informasi dan perkembangannya. Melalui berbagai pengembangan dibidang informasi dan teknologi maka bank dituntut selalu mengikuti kemudahan akses setiap saat pada perangkat lunak yang sedang berkembang saat ini dan dimasa yang akan datang.

Reliability atau keandalan layanan ebanking merupakan faktor utama karena tanpa keandalan ini maka nasabah tidak dapat menggunakan fitur-fitur yang tersedia sehingga diperlukan kemampuan teknologi yang mampu menjaga ketersediaan aplikasi e-banking yang baik.

\section{Pengaruh variabel Responsiveness terhadap variabel Kepuasan}

Responsiveness diukur sejauh mana tingkat daya tanggap nasabah dalam upaya mendukung kepuasan dalam bertransaksi dengan e-banking. Hasil penelitian menunjukkan bahwa variabel Responsiveness berhubungan positif tidak signifikan terhadap kepuasan nasabah e-banking. Hal ini ditunjukkan oleh nilai signifikansinya bernilai 0,225 > 0,05 dan nilait T-test nya sebesar 1,219. Berdasarkan hasil uji statistik maka variabel Responsiveness tidak selalu menjadi pendorong kepuasan nasabah dalam transaksi e-banking. Besarnya rata-rata pendapat responden terhadap item pernyataan Responsiveness yang menyatakan setuju dengan 
skor sebesar 4,07 dari maksimal skor 5. Hal ini menunjukkan secara keseluruhan variabel Responsiveness tidak signifikan terhadap kepuasan nasabah dengan kata lain variabel Responsiveness dalam penelitian saat ini bukan penentu kepuasan nasabah. Item yang memiliki skor tertinggi yaitu Aplikasi ebanking bank di Indonesia mudah dioperasikan dengan skor 4,14 dari total skor 5, esdangkan item Aplikasi e-banking bank di Indonesia relative berproses cepat dalam sebuah transaksi memiliki skor tertinggi kedua yaitu sebesar 4,11 dari total skor 5 . Item Informasi dalam aplikasi $e$-banking bank di Indonesia mudah dipahami dengan skor jawaban responden sebesar 3,95 yaitu skor lebih rendah dibandingkan item lainnya yaitu e-banking bank di Indonesia mengutamakan prinsip tepat waktu dalam layanan memiliki skor jawaban sebesar 4,06 dengan kategori setuju.

Hubungan antara variabel Responsiveness dengan kepuasan adalah berhubungan positif tidak signifikan. Hal ini berbeda dengan penelitian Al Dugaishem dan Khawaja (2017), Khan et al. (2018) yang menyatakan bahwa variabel Responsiveness berpengaruh positif signifikan terhadap kepuasan nasabah. Hal ini bukan berarti item-item dalam variabel Responsiveness tidak mendukung kepuasan nasabah tetapi hal-hal terkait kemudahan, kecepatan, mudah dipahami dan tepat waktu bukan lagi menjadi faktor penentu nasabah untuk melakukan transaksi dengan e-banking tetapi faktor-faktor tersebut sudah secara otomatis akan dirasakan nasabah ketika sudah semakin biasa melakukan transaksi e-banking.

Hasil ini juga didukung dengan karakteristik responden yaitu 60 responden atau $45,5 \%$ berpendidikan S1 sedangkan 57 responden atau $43,2 \%$ berpendidikan S2 sedangkan sisanya 10 responden berpendidikan sampai dengan SMA dan 5 responden berpendidikan S3. Selain itu pekerjaan responden juga mendukung transaksi menggunakan e-banking yaitu: Karyawan swasta sebanyak 82 responden $(62,12 \%)$; PNS 23 responden $(17,42 \%)$; Wiraswasta 15 responden (11,36\%) dan sisanya sebanyak 12 responden $(9,09 \%)$ menyatakan belum bekerja. Semakin tinggi tingkat pendidikan semakin mudah tingkat pemahaman dan kemauan untuk bertransaksi dengan $e$ banking. Sedangkan dukungan pekerjaan mendorong nasabah menggunakan ebanking dalam lingkungan pekerjaan baik antar perusahaan dengan karyawan maupun dengan mitra kerja.

Faktor responsiveness dalam layanan $e$ banking menjadi faktor sekunder yang tetap perlu ditingkatkan karena responsiveness ini berkenaan dengan kemudahan, kecepatan, dan ketepatan layanan e-banking. Setelah $e$ banking mampu andal tersedia maka nasabah akan merasakan kemudahan mengoperasikan, kemudahan mempelajari, kecepatan proses transaksi, dan ketepatan dalam proses transaksi e-banking.

\section{Pengaruh variabel Assurance terhadap variabel Kepuasan}

Assurane adalah hal-hal yang dapat menjamin kepuasan nasabah dalam Transaksi e-banking. Hasil penelitian menunjukkan bahwa variabel Assurance berpengaruh positif tidak signifikan terhadap kepuasan nasabah e-banking. Hal ini ditunjukkan oleh nilai signifikansinya bernilai 0,147 >0,05 dan nilait T-test nya sebesar 1,459. Berdasarkan hasil uji statistik maka variabel Assurance tidak selalu menjadi pendorong kepuasan nasabah dalam transaksi $e$-banking. Hasil penelitian ini tidak sejalan dengan hasil penelitian Pakurar et al. (2019), Khan et al. (2018).

Hasil penelitian menunjukkan item-item pernyataan dalam variabel Assurance yaitu item yang memiliki skor tertinggi adalah $e$ banking bank di Indonesia memproses transaksi dengan benar dengan skor 4,13 dari total skor 5. Skor tertinggi kedua didukung dari item pernyataan Aplikasi ebanking bank di Indonesia menyajikan informasi yang berkualitas dengan skor sebesar 3,89. Item pernyataan $e$-banking bank di Indonesia menyimpan data dengan aman memiliki skor 3,67. Item pernyataan Bank di 
Indonesia memberi edukasi yang memadai kepada nasabah tentang keamanan menggunakan e-banking memiliki skor terendah yaitu sebesar 3,56. Hal ini mungkin didasari atas ketidaktahuan responden apakah ada edukasi yang diberikan bank dalam penggunaan e-banking secara terus menerus dari pihak bank ataukah hanya pada saat awal nasabah membuka rekening atau jika ada masalah dengan transaksi secara offline saja.

Variabel Assurance berpengaruh positif tidak signifikan terhadap kepuasan artinya bahwa dalam penelitian ini responden merasakan hal-hal yang menjadi jaminan menggunakan e-banking bukan lagi menjadi faktor penentu apakah harus menggunakan $e$-banking atau tidak menggunakan $e$-banking, apalagi dimasa pandemi covid 19 saat ini dimana hampir semua orang sangat disarankan untuk tidak keluar rumah maka praktis transaksi perbankan juga dilakukan di Arumah. Sehingga hasil penelitian ini memang sangat mungkin terjadi perbedaan dengan hasil-hasil penelitian yang lain mengingat 1 ) penelitian sebelumnya dilakukan saat $e$ banking belum menjadi kebutuhan utama; 2) penelitian sebelumnya dilakukan pada Ikayah dan responden yang berbeda; 3) penelitian saat ini dilaku-kan pada situasi dimana perekonomian sedang tidak stabil saat terjadinya pandemi covid 19.

Variabel Assurance merupakan faktor sekunder yang perlu diperhatikan oleh bank, jaminan atas keamanan, jaminan atas edukasi, jaminan komunikasi yang baik dengan didukung kemampuan personil yang dijamin baik pula dalam melayani.

\section{Pengaruh variabel Tangibles terhadap variabel Kepuasan}

Hal-hal yang terkait dengan tampilan, fitur dan kualitas informasi yang baik adalah hal-hal yang dapat mengukur tingkat bukti nyata yang juga dapat mendorong tingkat kepuasan nasabah e-banking. Hasil penelitian ini menunjukkan bahwa variabel Tangibles berpengaruh positif tidak signifikan terhadap kepuasan nasabah e-banking. Hal ini ditunjukkan oleh nilai signifikansinya berni- lai 0,332 >0,05 dan nilait T-test nya sebesar 0,973 . Hasil penelitian ini berbeda dengan hasil penelitian Khan et al. (2018).

Berdasarkan hasil uji statistik maka variabel Tangibles tidak selalu menjadi pendorong kepuasan nasabah dalam transaksi $e$ banking. Jawaban responden terhadap itemitem pernyataan dalam Variabel Tangibles dimana rata-rata responden menjawab setuju atas item yang dinyatakan dalam kuesioner dengan skor sebesar 3,86. Pada variabel Tangibles, Skor tertinggi dari item Personil bank melayani nasabah dengan ramah dalam layanan e-banking bank di Indonesia dengan skor sebesar 3,97

Skor item tertinggi kedua adalah item Personil bank melayani nasabah dengan professional dalam layanan e-banking di Indonesia dengan skor 3,92. Hal ini menunjukkan bahwa seorang nasabah selain butuh pelayanan yang baik dari karyawan bank juga membutuhkan layanan yang profesional agar tercipta layanan yang adil. Item yang lain memiliki skor yang tidak jauh berbeda adalah item Aplikasi e-banking Bank di Indonesia memiliki fitur yang relative lengkap dengan skor sebesar 3,82. Item dengan skor terendah adalah item Aplikasi e-banking Bank di Indonesia tampilannya menarik dengan skor 3,72.

Faktor Tangibles pada layanan e-banking merupakan factor sekunder, memang nasabah tidak melihat personil bank yang melayani, tidak melihat gedung atau lokasi bank, karena nasabah cukup bertransaksi melalui layanan e-banking.

\section{Pengaruh variabel Empathy terhadap variabel Kepuasan}

Empathy dalam penelitian ini adalah upaya bank berkaitan dengan pemenuhan kebutuhan transaksi nasabah, edukasi, mengatasi kesulitan nasabah, dan komunikasi dengan nasabah dalam layanan e-banking. Hasil penelitian ini menunjukkan bahwa tingkat Empathy responden terhadap layanan e-banking berpengaruh signifikan positif terhadap kepuasan nasabah ditunjukkan oleh nilai signifikansinya bernilai 0,004 < 
0,05 dan nilait T-test nya sebesar 2.975. Hasil penelitian ini sejalan dengan penelitian Lomendra et al (2019), Al Dugaishem dan Khawaja (2017), Khan et al. (2018).

Hasil penelitian terhadap 132 responden rata-rata skor jawaban responden atas keseluruhan item pernyataan dalam variabel Emphaty sebesar 3,91 yang masuk kategori setuju. Item pernyataan dengan skor tertinggi adalah item e-banking bank di Indonesia mampu melayani kebutuhan transaksi nasabah dengan skor 4,12. Item dengan skor tinggi kedua kedua sebesar 3,96 adalah item Bank membantu nasabah dengan baik dalam mengatasi kesulitan dalam penggunaan aplikasi e-banking bank di Indonesia, sedangkan item Bank membangun komunikasi yang baik dengan nasabah dalam layanan e-banking bank di Indonesia dengan skor 3,89, dan item Edukasi nasabah dijalankan dengan baik oleh bank dengan skor terendah sebesar 3,68.

Pengaruh variabel Emphaty terhadap kepuasan nasabah dilatar belakangi adanya kendala nasabah dalam penguasaan teknologi bank sehingga dibutuhkan perhatian dan kepedulian bank untuk mengedukasi, mau memperhatikan kebutuhan transaksi nasabah, dan mau mencarikan solusi ketika nasabah mengalami masalah, tentunya melalui komunikasi yang baik agar timbul kepuasan nasabah.

\section{Implikasi Penelitian}

Kepuasan nasabah terhadap penggunaan electronic banking bank tidak semata-mata hanya ditunjukkan melalui sikap dan keputusan nasabah untuk terus atau berhenti menggunakan $e$-banking. Manfaat $e$ banking yang memudahkan nasabah untuk melakukan transaksi keuangan, tanpa harus nasabah datang ke bank dapat mempengaruhi penilaian dan keputusan nasabah untuk terus menggunakan $e$-banking.

Pada perspektif yang lain, dimana nasabah dapat dipengaruhi oleh promosi bank lain memungkinkan nasabah berpindah ke bank lain karena layanan e-banking yang lebih baik, dan hal ini merupakan tantangan bagi bank untuk terus meningkatkan layanannya sehingga dapat memenangkan persaingan di industri perbankan.

Hasil penelitian ini menunjukkan bahwa beberapa variabel dapat mempengaruhi kepuasan nasabah yakni variabel Reliability dan variabel Empathy berpengaruh signifikan positif terhadap Kepuasan nasabah, hal ini menunjukkan bahwa keandalan layanan e-banking menuntut bank memiliki aplikasi e-banking yang tersedia dan dapat diakses dengan baik oleh nasabah sehingga nasabah dapat menggunakan berbagai fitur layanan pada e-banking merupakan faktor penting untuk memuaskan nasabah.

Variabel Empahty menuntut bank untuk peduli atas nasabahnya, peduli atas kesulitan dalam mengoperasionalkan e-banking, peduli atas pentingnya mengedukasi nasabah. Electronic banking adalah layanan bank berbasis teknologi informasi dan komunikasi, teknologi bank yang tersedia digunakan oleh nasabah akan memberikan manfaat bagi nasabah jika teknologi bank tidak mengalami error, e-banking dapat diakses. Selain e-banking tersedia dapat diakses dengan baik maka persoalan yang tidak kalah pentingnya adalah bagaimana kemudahan menggunakannya, kesulitan nasabah dalam menggunakan e-banking menuntut adanya bantuan dari bank untuk mampu memberikan pertolongan melalui edukasi dan penanganan keluhan nasabah. Dengan demikian, nasabah merasakan kenyamanan dan kepuasan atas layanan e-banking bank.

Implikasi manajerial di dunia perbankan, Reliability dan Emphaty. Variabel Reliability yang kuat berarti adanya kemampuan teknologi e-banking yang mampu berjalan pada segala kondisi akses internet, baik saat jalur internet mengalami kelambatan maupun saat kondisi akses internet cepat. Sedangkan, Emphaty menuntut kemampuan Sumber Daya Manusia bank yang lebih baik dalam melayani dengan cepat, tepat, dan memuaskan nasabah. Sumber daya manusia bank yang memiliki kepedulian dan pengetahuan tentang e-banking. 
Hasil penelitian ini sejalan dengan penelitian Lomendra et al (2019) yang juga menyimpulkan bahwa variabel Reliability dan Emphaty berpengaruh signifikan terhadap kepuasan nasabah di bank, setelah menguji lima dimensi kualitas layanan dengan menggunakan 200 nasabah bank.

Manajer Bank perlu menetapkan program untuk memperkuat Aspek Reliability dan Emphaty dengan memperkuat dua faktor, yakni faktor teknologi dan faktor non teknologi. Faktor teknologi adalah kekuatan teknologi yang sengaja diadopsi untuk meningkatkan keandalan layanan seiring dengan peningkatan volume transaksi terutama pada nasabah corporate sehingga butuh teknologi yang tidak gagal akses karena memproses volume transaksi yang besar. Demikian juga, faktor non teknologi perlu diperkuat pada kemampuan dan sikap personil bank untuk dapat melayani dengan ramah, cepat, dan tepat solusi, serta dengan kemampuan mengedukasi nasabah. Penguatan faktor teknologi dan faktor non teknologi menuntut kemampuan bank untuk menyediakan anggaran yang cukup untuk penguatan kedua faktor tersebut.

Hasil Penelitian ini juga memberikan implikasi teoritis bahwa konsep tentang Reliability dalam pemanfaatan jasa menggunakan teknologi informasi menjadi faktor utama karena tanpa ketersediaan teknologi dalam layanan maka pemanfaatan teknologi tidak dapat terjadi dan tujuan utama layanan bank juga menjadi tidak tercapai. Untuk variabel Emphaty dalam implementasi layanan jasa mengarah pada pemenuhan kebutuhan nasabah, saat nasabah menghadapi kendala maka timbul kebutuhan berupa pencarian solusi sehingga peranan bank penting untuk mengenali apa yang menjadi kebutuhan nasabah.

Implikasi manajerial dan implikasi teoritis menempatkan kekuatan utama layanan $e$-banking tidak semata-mata pada aspek teknologi, tapi tetap pada aspek manusia. Kemudahan, Kecepatan, Ketepatan layanan tetap harus ditingkatkan namun yang menjadi prioritas utama adalah peningkatan Reliability dan Emphaty.

\section{SIMPULAN DAN SARAN}

Berdasarkan hasil uji statistik, analisis statistik dan pembahasan maka dapat ditarik kesimpulan bahwa variabel Reliability dan variabel Empathy berpengaruh signifikan positif terhadap Kepuasan nasabah, hal ini berarti bahwa semakin tinggi tingkat Reliability dan Empathy nasabah pada ebanking bank maka semakin tinggi pula kepuasan yang dirasakan nasabah terhadap produk e-banking. Sedangkan variabel Responsiveness, Assurance dan Tangibles berpengaruh positif tidak signifikan terhadap Kepuasan nasabah pengguna e-banking bank. Hal ini berarti ketiga variabel tersebut tidak menjadi penentu faktor kepuasan nasabah $e$ banking di Indonesia.

Disarankan bagi perbankan di Indonesia untuk terus meningkatkan dan memperkuat layanannya terutama memperkuat Reliability dan Empathy karena memiliki pengaruh yang signifikan terhadap variabel Kepuasan Nasabah. Sedangkan saran untuk peneliti yang lain adalah memperluas variabel yang diuji dalam penelitian e-banking dengan kajian literatur yang lebih banyak, karena masih ada variabel lain sebesar $47,8 \%$ diluar model penelitian ini yang perlu dikaji lebih mendalam.

Disarankan bagi peneliti lainnya untuk melanjutkan penelitian ini dengan melihat perspektif bank sebagai pihak penyelenggara e-banking yang juga memiliki kepentingan utama untuk melayani nasabah dengan baik dan merupakan tantangan persaingan di industri bank untuk bisa memberikan layanan yang memuaskan. Demikian juga, masih perlu dilakukan riset dengan pendekatan kualitatif tentang bagaimana nasabah menilai penguatan aspek teknologi dan aspek non teknologi berjalan secara seimbang dalam layanan perbankan.

Disarankan bagi pemerintah sebagai pembuat regulasi untuk mengatur tentang penggunaan teknologi terutama di sector strategis seperti perbankan yang dapat 
meningkatkan keandalan teknologi sehingga pelanggan dapat meraih manfaat yang lebih banyak.

\section{DAFTAR PUSTAKA}

Al Dugaishem, F. A. dan M. J. Khawaja. 2017. Customer Satisfaction with Islamic Banks: A Case Study of Al Rajhi Bank. Tazkia Islamic Finance and Business Review 11(1):57-80.

Al-Hawary, S. I. S. dan W. F. Al-Smeran. 2017. Impact of Electronic Service Quality on Customers Satisfaction of Islamic Banks in Jordan. International Journal of Academic Research in Accounting, Finance and Management Sciences 7(1): 170-188.

Ejigu, S. N. 2016. E-Banking Service Quality and Its Impact on Customer Satisfaction in State Owned Banks in East Gojjam Zone Ethiopia. Journal of Economics and Sustainable Development 7(21): 100-110.

Fida, B. A., U. Ahmed, Y. Al-Balushi, dan D. Singh. 2020. Impact of Service Quality on Customer Loyalty and Customer Satisfaction in Islamic Banks in the Sultanate of Oman. SAGE Journal 10(2): 1-10.

Firdous, S. dan R. Faroqi. 2017. Impact of Internet Banking Service Quality on Customer Satisfaction. Journal of Internet Banking and Commerce 22(1):1-17.

Gupta, K. K. dan I. Bansal. 2012. Development of an Instrument to Measure Internet Banking Service Quality in India. Journal of Arts, Science $\mathcal{E}$ Commerce 3(2):11-25.

Hair, J. F., W. C. Black, B. J. Babin, dan R. E. Anderson. 2018. Multivariate data analysis. Pearson Prentice Hall. London

Khan, A. G., R. P. Lima, dan M. S. Mahmud. 2018. Understanding the Service Quality and Customer Satisfaction of Mobile Banking in Bangladesh: Using a Structural Equation Model. Global Business Review 22(1): 85-100.

Kotler, P. dan K. L. Keller. 2016. Manajemen Pemasaran. Erlangga. Jakarta.
Lomendra, V., P. Sharmila, J. Roubina, D. Ganess, dan S. N. M. Zabeen. 2019. Assessing The Dimensions on Customer Satisfaction in Commercial Banks of Mauritius. Studies in Business and Economics 14(1): 259-270

Mohalingam, B. dan C. Janathanan. 2018. Impact of Electronic Banking on Customer satisfaction. Prosiding APIIT Business, Law \& Technology Conference: 1-10

Nagar, N. dan E. Ghai. 2019. A Study of Bank Customer's Reliability towards Electronic Banking (E-Banking) Channel's!. International Journal of Management Studies 6(1): 34-40.

Nimako, S. G., N. K. Gyamfi dan A. M. M. Wandaogou. 2013. Customer Satisfaction with Internet Banking Service Quality in The Ghanaian Banking Industry. International journal of scientific \& technology research 2(7):165-175.

Pakurar, M., H. Haddad, J. Nagy, J. Popp, dan J. Olah. 2019. The Service Quality Dimensions that Affect Customer Satisfaction in the Jordanian Banking Sector. Journal of Sustainability 11(1): 1-24.

Tjoanoto, M. T. 2013. Pengaruh Service Quality terhadap Customer Satisfaction di Restoran Jade Imperial. Jurnal Manajemen Pemasaran Petra 1(1): 1-9.

Uwalaka, S. C. dan P. Eze. 2020. Effect of Mobile Banking On Customers Satisfaction In Commercial Banks In Anambra State. International Journal of Innovative Social Sciences \& Humanities Research 8(1): 101-109.

Vetriel,S. C.,J.Rajini, dan V. Krishnamoorthy. 2020. Service quality delivery through Web sites: A critical review of extant know. Journal Academy of Marketing Science 7(2): 546-551.

Yusuf, E. E. dan A. Bala. 2015. Empirical Analysis of Service Quality, Reliability and End-User Satisfaction on Electronic Banking in Nigeria. IOSR Journal of Business and Management (IOSR-JBM) 17(10):28-34. 